\title{
Traditional and Developing Segments of the Sharing Economy from the Point of View of Customers
}

\author{
Libena Tetrevova, Martina Jelinkova, Simona Munzarova
}

University of Pardubice

Studentska 95, 53210 Pardubice, Czech Republic

E-mail.libena.tetrevova@upce.cz; martina.jelinkova@upce.cz; simona.munzarova@upce.cz

cross $^{\text {ref }}$ http://dx.doi.org/10.5755/j01.ee.32.5.28337

\begin{abstract}
The sharing economy represents a phenomenon which is increasing in importance as time goes by, even from the point of view of less developed countries. The aim of the study is to evaluate the knowledge of traditional and developing segments of the sharing economy and their platforms and to analyse and evaluate the level of their use employing the example of customers (the younger and the older generation) in one of the post-communist countries - the Czech Republic. Data was collected on the basis of a questionnaire survey $(N=614)$. This was processed using descriptive statistics tools. The study shows that respondents are the most familiar with forms of sharing not only from traditional segments (passenger transportation and accommodation) but also from the financial segment. The best-known platforms include Uber, Airbnb and Zonky. Platforms from traditional segments are used the most. The younger generation has better awareness, both about possible forms of sharing and also about the existing platforms. However, the study did not prove any differences in the level of use of platforms between the younger and older generation.
\end{abstract}

Keywords: Sharing Economy; Collaborative Consumption; P2P Sharing; Sharing Accommodation; Carpooling; Sharing Finances.

\section{Introduction}

The sharing economy represents one of the fastest developing phenomena in history, development of information and communication technologies in particular contributing towards its evolution (Hamari et al., 2016; Lessem et al., 2016). A logical condition for its development is growth in awareness of this phenomenon (Hamari et al., 2016). The number of research papers on this topic has been increasing since 2011 (Cheng, 2016), achieving a level of 2,750 papers registered in the Web of Science database in July 2021. The above-mentioned papers are in particular devoted to the business models of the sharing economy and its impacts (Cheng, 2016), e.g. Kathan et al., 2016; Munoz \& Cohen, 2017; Siuskaite et al., 2019. Some authors discuss the context of the sharing economy and sustainability (e.g. Geissinger et al., 2019; Laukkanen $\&$ Tura, 2020) or, to a lesser scope, the individual sharing platforms (e.g. Adamiak, 2019; Pepic, 2018; StanoevskaSlabeva et al., 2017), whereas the studies about tourism and transport are dominant (Anglada \& Hernandez Lara, 2020). The accommodation and transport segments represent established, traditional segments of the sharing economy (Schor, 2016; Schor \& Cansoy, 2019; Zhang et al., 2019).

However, only a few studies so far have been devoted to more in-depth investigation into the awareness of customers about this phenomenon and the levels of use of the services in the sharing economy (Andreotti et al., 2017b). We can mention the study by Kim et al. (2018), which was performed in 2016 and which investigates the consequences of the awareness of respondents about the sharing economy using the example of the Republic of Korea. However, considering the speed in which the phenomenon of the sharing economy is developing, it is necessary to push knowledge in this field further. This was, for example, attempted by Andreotti et al. (2017b), whose study on the awareness of the sharing economy and participation in its activities from the point of view of the inhabitants of twelve European countries may be regarded as very beneficial. However, no Eastern European country was included in this study with an exception of Poland. The fact of the matter is that the sharing economy model is in particular established in the United States and Western Europe (Radwan et al., 2019). The question, therefore, is what the level of knowledge about and the level of use of sharing economy services and sharing economy platforms in the countries of Eastern Europe is. This is a topic which, so far, has not been part of the mainstream investigation. Only partial data is available on the level the citizens of the EU 28 countries used sharing economy services in six selected segments, these specifically being the segments of transport, accommodation, food-related services, household services, professional services and collaborative finance, published in 2018 by Eurobarometer (2018). It is evident from the aforementioned that until now the authors have devoted their efforts for the resolution of other issues. Only insignificant research has been performed into the given phenomenon from the point of view of customers who are the key component and driving force behind the sharing economy. In addition to this, the authors devoted their research to the phenomenon of sharing economy mainly from the point of view of developed countries and neglected the study of this issue from the point of view of postcommunist countries, which could be a source of interesting findings. A significant gap in the research is, therefore, evident, as is the need to develop knowledge in this area and contribute towards the development of the theory and practice of sharing economy. The aim of the study is to evaluate the 
knowledge of traditional and developing segments of the sharing economy and their platforms and to analyse and evaluate the level of their use employing the example of customers (the younger and the older generation) in one of the post-communist countries - the Czech Republic.

Primary data, acquired in the form of a questionnaire survey using a sample of 614 respondents, are analysed in the article using descriptive statistics tools. Analysis and evaluation are performed on the level of knowledge about and the level of use of sharing economy services and their platforms by customers in the Czech Republic. Differences are examined not only from the point of view of the segments of the sharing economy and their platforms (traditional versus developing segments), but also from the point of view of various age groups of respondents (the younger versus the older generation). The findings are subsequently discussed in the context of the relevant international studies.

\section{Literature Review and Hypotheses}

There is no comprehensive conceptual approach to the phenomenon of the sharing economy (Gerwe \& Silva, 2020), the reason for this being its diversity combined with the existence of many platform and various types of sharing (Habibi et al., 2016). In addition to this, several other terms are also used to identify it other than the term sharing economy, e.g. the original (Schor \& Cansoy, 2019) collaborative consumption (Botsman \& Rogers, 2011), a term which is however found less these days (Anglada \& Hernandez Lara, 2020). We can also come across other alternative terms, e.g. the term collaborative economy (European Commission, 2016; Gruszka, 2017; McKee, 2017). The most popular expressions are sharing economy and collaborative consumption (Gorog, 2018; Anglada \& Hernandez Lara, 2020). In addition to this, these terms are not even defined in a uniform manner (Gorog, 2018; Anglada \& Hernandez Lara, 2020). Each of the many authors devotes their attention to a different aspect of this phenomenon (De Rivera et al., 2017; Godelnik, 2017). For example, Botsman \& Rogers (2011, p. xv) focus on the possible forms of sharing and state that collaborative consumption includes "traditional sharing, bartering, lending, trading, renting, gifting and swapping, redefined through technology and peer communities". Voytenko Palgan et al. (2017, p. 71) define the term sharing economy from the point of view of possible sharing initiatives, stating that we can define the sharing economy as "a variety of bottom-up initiatives, public-private-people partnerships, business start-ups and local government schemes, all of which utilise the idling capacity of our material world". A common trait to be found in many definitions of the term sharing economy, but also alternative terms, is the possibility of sharing unused assets (Voytenko Palgan et al., 2017). The definition, for example by Frenken \& Schor (2017, pp. 4-5), is based on emphasis of this aspect of sharing, according to whom the essence of the sharing economy consists in "consumers granting each other temporary access to under-utilised physical assets ("idle capacity"), possibly for money". Guyader \& Piscicelli (2019, p. 1061) also draw attention to the key aspect of unused assets, according to whom the sharing economy represents "an umbrella term for business and consumption practices that are based on sharing underutilised resources (e.g., goods, services, and spaces) for free or for a fee, typically enabled by online platforms and peer communities". Comprehensive definition of this phenomenon is offered by the European Commission which uses the term collaborative economy (European Commission, 2016). According to the European Commission (2016, p. 3) "collaborative economy refers to business models where activities are facilitated by collaborative platforms that create an open marketplace for the temporary usage of goods or services often provided by private individuals"; these transactions generally do not involve a change of ownership and can be carried out for profit or not-for-profit.

We can distinguish many forms of sharing (Table 1). From the point of view of entities which are involved, we can regard $\mathrm{C} 2 \mathrm{C}$ (customer to customer) sharing, or $\mathrm{P} 2 \mathrm{P}$ (peer to peer) sharing (Guyader, \& Kienzler, 2019), and B2C (business to customer) sharing (Ertz et al., 2017; Puschmann \& Alt, 2016; Radwan et al., 2019) as the two basic concepts. Some authors further distinguish B2B (business to business) sharing (Demary, 2015; Sujova \& Remen, 2018; Tetrevova \& Kolmasova, 2021), B2G (business to government) sharing (Richter \& Slowinski, 2018) and G2G (government to government) sharing (Ertz et al., 2017) from the point of view of the entities involved. $\mathrm{B} 2 \mathrm{U}$ (business to university) sharing also comes into consideration, as does U2B (university to business) sharing or U2G (university to government) sharing (Tetrevova \& Vlckova, 2018, 2019).

We can also differentiate sharing from the point of view of the technology used, this being into sharing with use of online platforms (Ertz et al., 2019; May et al., 2017; Richardson, 2015; Sutherland \& Jarrahi, 2018) and sharing without use of online platforms (Ertz et al., 2019; Schor, 2016). Ertz et al. (2019) further classify sharing with use of online platforms into pure online sharing, sharing in which the online platform is a major component, sharing in which the online platform is a facilitating component and sharing in which the online platform is a minor component.

Motives leading economic entities to share may be driven by profit or not (Belk, 2014; Schneider, 2017; Schor \& Cansoy, 2019). If the motive is profit, we talk of commercial sharing (Bucher et al., 2016). If the motive is not to make a profit, this may be altruism (Andreotti et al., 2017b; Bucher et al., 2016; Harvey et al., 2020), this then concerns so-called charitable sharing (Tetrevova, 2020). However, the motive may also be compensation of costs (Ertz et al., 2019) and we can label this form of sharing hybrid (Tetrevova, 2020). A different view of non-profit motives for sharing is provided by Schor \& Cansoy (2019), according to whom, the possible motive for sharing may be an effort to gain new friends or experiences, or an effort to minimise negative impacts on the environment. A contribution towards sustainability in the economic, social and environmental fields is deemed to be the original (Geissinger et al., 2019) and the key (Barnes \& Mattsson, 2016; Habibi, 2019) motive for sharing.

In general, from the point of view of the subject of sharing, it is possible to share products (Harvey et al., 2020), money (Barnes \& Mattsson, 2016), services (Cheng et al., 2019) or knowledge and abilities (Barnes \& Mattsson, 
2016). In relation to this typology, we can distinguish the following key forms of the sharing economy:

- carsharing (Bellos et al., 2017; Standing et al., 2019);

- $\quad$ carpooling/ridesharing (Standing et al., 2019; Zhu et al., 2017);

- electric scooter sharing and bicycle sharing (Geissinger et al., 2019; Mi \& Coffman, 2019);

- shared transport of goods or food (Cohen \& Munoz, 2016; Ferrell at al., 2017; Geissinger et al., 2019);

- $\quad$ sharing accommodation (Bokyeong \& Cho, 2016; Casado-Diaz et al., 2020);

- sharing tools and equipment (e.g. machinery, equipment, tools, sporting equipment or furniture) (Belk, 2014; Ferrell at al., 2017);
- $\quad$ sharing space (e.g. parking spaces, storage space, premises for DIY) (Cohen \& Munoz, 2016; Geissinger et al., 2019);

- sharing services (e.g. cleaning, childminding, looking after and caring for pets or repairs) (Ferrell at al., 2017; Zhang et al., 2019);

- $\quad$ sharing work or time (e.g. occasional work while employed, consultancy) (Ferrell et al., 2017; Markendahl et al., 2018);

- $\quad$ sharing finances (loans and investment) (Leone \& Schiavone, 2018; Wei \& Lin, 2017);

- $\quad$ sharing insurance (Milanova \& Maas, 2017);

- shared education (e.g. language preparation or textbooks) (Geissinger et al., 2019; Markendahl et al., 2018);

- $\quad$ shared entertainment (e.g. books, games, films or music) (Belk, 2014; Geissinger et al., 2019).

Table 1

Typology of Sharing

\begin{tabular}{|c|c|c|c|c|}
\hline Aspect & Entities involved & Technical means & Motive for sharing & Subject of sharing \\
\hline $\begin{array}{l}\text { Specific } \\
\text { forms of } \\
\text { sharing }\end{array}$ & $\begin{array}{l}\text { - } \mathrm{C} 2 \mathrm{C}(\mathrm{P} 2 \mathrm{P}) \text { sharing } \\
\text { - } \mathrm{B} 2 \mathrm{C} \text { sharing } \\
\text { - } \mathrm{B} 2 \mathrm{~B} \text { sharing } \\
\text { - } \mathrm{B} 2 \mathrm{G} \text { sharing } \\
\text { - } \mathrm{G} 2 \mathrm{G} \text { sharing } \\
\text { - } \mathrm{B} 2 \mathrm{U} \text { sharing } \\
\text { - } \mathrm{U} 2 \mathrm{~B} \text { sharing } \\
\text { - } \mathrm{U} 2 \mathrm{G} \text { sharing }\end{array}$ & $\begin{array}{l}\text { - pure offline sharing } \\
\text { - online sharing } \\
\text { * online platform as } \\
\text { minor component } \\
\text { * online platform as } \\
\text { facilitating component } \\
\text { * online platform as } \\
\text { major component } \\
\text { * pure online }\end{array}$ & $\begin{array}{l}\text { - commercial } \\
\text { sharing } \\
\text { - charitable sharing } \\
\text { - hybrid sharing }\end{array}$ & $\begin{array}{l}\text { - } \text { carsharing } \\
\text { - carpooling } \\
\text { - electric scooter sharing } \\
\text { - bicycle sharing } \\
\text { - shared transport of goods or food } \\
\text { - sharing accommodation } \\
\text { - sharing tools and equipment } \\
\text { - sharing space } \\
\text { - sharing services } \\
\text { - sharing work or time } \\
\text { - sharing finances } \\
\text { - sharing insurance } \\
\text { - shared education } \\
\text { - shared entertainment }\end{array}$ \\
\hline
\end{tabular}

Within the European Union, we can find both platforms originating in Europe (mainly from France and the UK) and platforms originating in other countries (typically the US) (Fabo et al., 2017). Local European platforms predominate (Stanoevska-Slabeva et al., 2017). In the most cases (approx. $90 \%$ ), these are for-profit platforms (StanoevskaSlabeva et al., 2017). A lot of them (approx. $36 \%$ ) are constituted by platforms with a turnover of up to EUR 1 million (Fabo et al., 2017). Really large platforms generating a turnover of more than EUR 100 million constitute approx. $15 \%$ of platforms (Fabo et al., 2017). An interesting fact is that platforms of domestic origin constitute almost half of all platforms operating in the Czech Republic (Fabo et al., 2017). However, use of sharing economy platforms is not very widespread in the Czech Republic for the time being. For example, shared accommodation was used by only $5 \%$ of Czechs (European Commission, 2019) and shared transport by only $3 \%$ of Czechs (Czech Statistical Office, 2018) in 2018.

The above-mentioned sharing segments develop at a different speed. According to Zhang et al. (2019, p. 7) "in this context, the lodging and transportation sectors can be considered the pioneers of peer-to-peer business". Schor \&
Cansoy (2019) also came to a similar conclusion, according to whom, accommodation and carpooling can be regarded as successfully established segments of commercial sharing. Schor (2016, p. 9) even states that "Airbnb (note: a sharing economy platform in the field of accommodation) is practically synonymous with the sharing economy". A conclusion regarding perception of the accommodation and transport segments as established, or traditional segments of the sharing economy is also drawn by the study performed by Bocker \& Meelen (2017), Cheng (2016), Frenken \& Schor (2017), or Godelnik (2017). According to the majority of experts, the reason for this is operations performed by the multinational giants Airbnb and Uber in the given segments of the sharing economy (PwC, 2015; Schor \& Cansoy, 2019), associated with their extensive investments (Godelnik, 2017). In the case of the transport segment, positive environmental impacts can also be regarded as a reason (Nijland \& van Meerkerk, 2017). Further growth of these traditional segments of the sharing economy is anticipated in future, but also the development of sharing in the field of collaborative finance, on-demand household services or on-demand professional services (PwC, 2016). The available data (Eurobarometer, 2018) and 
studies (Andreotti et al., 2017a; IPSOS, 2020) also show that services in the accommodation and transport segment rank among the most important in EU countries and are dominant within the framework of services used in the sharing economy. On the basis of the aforementioned, we can formulate hypotheses valid for the monitored group of Czech customers.

- hypothesis H1: “Customers are more familiar with options for sharing in the field of traditional segments of the sharing economy such as accommodation and transport as opposed to the other segments of the sharing economy.";

- hypothesis H2: "Customers are more familiar with the existence of platforms in the field of traditional segments of the sharing economy such as accommodation and transport as opposed to the other segments of the sharing economy.";

- hypothesis H3: "Customers use the services of platforms in traditional segments of the sharing economy such as accommodation and transport to a greater extent as opposed to services in other segments of the sharing economy.".

The awareness of the possibility of using services in individual segments of the sharing economy and the awareness about platforms of the sharing economy and the level of their use is, among other things, affected by age. According to Andreotti et al. (2017a), customers aged 1834 exhibit a greater level of the awareness of and participation in the sharing economy. A study performed by IPSOS (2020) came to a similar conclusion, according to which people aged 18-29 from large cities with more than 100,000 inhabitants are more frequently aware of platforms of the sharing economy. They also more frequently use sharing economy services and the services of the Uber and Airbnb platforms (IPSOS, 2020). We can also formulate hypothesis H4: "The younger generation is more aware of the possible forms of sharing in comparison with the older generation.", hypothesis H5: "The younger generation is more aware of the existence of platforms of the sharing economy in comparison with the older generation." and hypothesis H6: "The younger generation uses the services of individual platforms of the sharing economy to a greater extent in comparison with the older generation.".

The scope of knowledge and the level of use of services and individual platforms of the sharing economy is also influenced by other factors. It is affected positively by the level of education achieved (Andreotti et al., 2017a; Eurobarometer, 2018). A difference is also evident in the awareness of and the level of use of sharing economy services between people living in large cities and those living in the countryside, the rural population having lower awareness and using these services less (Dudek \& Sałek, 2016; Eurobarometer, 2018). On the contrary, no major differences in the awareness of and the level of use of sharing economy services between men and women were proven in the past (Andreotti et al., 2017a; Eurobarometer, 2018).

\section{Data and Methodology}

The aim of the study is to evaluate knowledge of traditional and developing segments of the sharing economy and their platforms and to analyse and evaluate the level of their use employing the example of customers (the younger and the older generation) in one of the post-communist countries - the Czech Republic. In the given context, the study should answer the following research questions:

1) To what extent are customers familiar with possibilities for sharing from the point of view of the individual segments of the sharing economy? Do any differences exist in familiarity of customers with possibilities for sharing from the point of view of traditional and developing segments of the sharing economy?

2) To what extent are customers familiar with the existence of platforms of the sharing economy? Do any differences exist in familiarity with platforms from the point of view of traditional and developing segments of the sharing economy?

3) To what extent do customers use the services of selected sharing economy services? Do any differences exist in use of the services of platforms of the sharing economy from the point of view of traditional and developing segments of the sharing economy?

4) Does the age of respondents have any impact on familiarity of customers with the possibilities of sharing, familiarity with platforms of the sharing economy or the level of their use?

The need to investigate the given issue from the point of view of a post-communist country such as the Czech Republic stems from the paradox which arises from the papers published so far. This is to say that on the one hand, the authors state that sharing is preferred in emerging economies as opposed to developed economies (Parente et $a l ., 2018)$. On the other hand, certain authors have come to the conclusion that sharing is used to a minimum extent in this country in comparison with the other countries of the European Union (Czech Statistical Office, 2018; European Commission, 2019).

The need to investigate knowledge and use of alternative sharing services and their platforms is given by the gap in research in this area, where authors have so far paid the minimum of attention to this topic. This assertation can be proven by the fact that there are only four publications on this topic registered in the Web of Science database as at 1 July 2021.

The reason for focusing on the aspect of age is in particular the fact that age plays a crucial role in the phenomenon of sharing, closely linked to ICT, as ElenaBucea et al. (2020) point out with reference to data provided by the United Nations. This is a key socio-demographic characteristic of all relevant research in this area, as evidenced by the studies performed to date, e.g. (Andreotti et al., 2017a).

On the basis of the literary research performed, the accommodation and passenger transportation segments are hereinafter regarded as traditional segments. The other segments are deemed to be developing segments.

Elaboration of the submitted study is based on systematic literary research. This was followed up with quantitative research, which allows for elimination or 
minimisation of the subjectivity of judgment (Kealey \& Protheroe, 1996), closely following of the original set of research goals, arrival at more objective conclusions, testing of the hypothesis, and identification of aspects of causality (Matveev, 2002). Primary data was obtained on the basis of a questionnaire survey performed from September to October 2019. A questionnaire survey was chosen with regard to its indisputable benefits consisting in low cost, relatively large sample sizes, and speed of data collection (Meadows, 2003; Thornton et al., 1997). The survey was conducted electronically, it being possible to fill in the questionnaire using the LimeSurvey application. The electronic form the survey was chosen in view of the fact that it is associated with benefits in the form of fewer missing data (Liaw, 2002) and saving on time relating to coding and analysis of data on a computer (Choy, 2014; Wright, 2006).

In view of the limits imposed by time, staffing numbers and finances, the quota sampling method was used for selection of respondents, this being the most commonly used method in sociological research (Chakrapani, 2000; Rada \& Martin, 2014). The quota characteristics, the most commonly used in sociological studies, were used, these being sex and age (Manstead \& Livingstone, 2012). Cross quotas were used. With its structure in line with the quota characteristics, the selection set corresponded to the structure of the population of the whole of the Czech Republic according to these check characteristics published on the website of the Czech Statistical Office and was made up of 630 respondents. The survey was performed using a network of interviewers from the ranks of the students of Pardubice University, who contacted the determined number of respondents on the basis of a breakdown of quotas and asked them to fill in the electronic questionnaire. A total of 614 completely filled-in questionnaires was received, this constituting a success rate of almost $98 \%$. The structure of respondents is evident from Tables 2-3.

Table 2

Structure of Respondents by Age

\begin{tabular}{|c|c|c|}
\hline Age & N & \% \\
\hline $15-29$ & 224 & $36 \%$ \\
\hline $30-80$ & 390 & $64 \%$ \\
\hline Total & $\mathbf{6 1 4}$ & $\mathbf{1 0 0} \%$ \\
\hline
\end{tabular}

Table 3

Structure of Respondents by Sex

\begin{tabular}{|l|c|c|c|c|c|c|}
\hline \multirow{2}{*}{ Sex/Age } & \multicolumn{2}{|c|}{$\mathbf{1 5 - 2 9}$} & \multicolumn{2}{c|}{$\mathbf{3 0 - 8 0}$} & \multicolumn{2}{c|}{ Total } \\
\cline { 2 - 7 } & $\mathbf{N}$ & $\mathbf{\%}$ & $\mathbf{N}$ & $\mathbf{\%}$ & $\mathbf{N}$ & $\mathbf{\%}$ \\
\hline Male & 114 & $51 \%$ & 192 & $49 \%$ & 306 & $50 \%$ \\
\hline Female & 110 & $49 \%$ & 198 & $51 \%$ & 308 & $50 \%$ \\
\hline Total & $\mathbf{2 2 4}$ & $\mathbf{1 0 0} \%$ & $\mathbf{3 9 0}$ & $\mathbf{1 0 0} \%$ & $\mathbf{6 1 4}$ & $\mathbf{1 0 0} \%$ \\
\hline
\end{tabular}

The questionnaire in particular included semi-closed questions, in which respondents chose several possible answers from the offer and were also able to add other options. This format ascertained familiarity among respondents with alternative forms of sharing, familiarity with the existence of individual platforms of the sharing economy and the level of use of individual platforms of the sharing economy. Closed questions were used for identification of respondents.
Primary data obtained via the questionnaire survey was processed using IBM SPSS Statistics, version 24 statistical software. Descriptive statistics tools were applied. Knowledge of forms of sharing and individual platforms of the sharing economy among respondents (both respondents as a whole and also with their division into the younger and the older generation) was analysed with the aid of relative frequencies. The scope of use of individual platforms of the sharing economy was also analysed using relative frequency. As regards analysis of differences in familiarity among the younger and the older generation with possibilities for sharing, the individual platforms of the sharing economy and differences in the level of their use, we used Pearson's chi-square test for the purpose of statistical validation of differences. Differences were tested at the 0.05 level of significance. Statistically significant differences are indicated in bold in the tables.

\section{Results}

\section{Knowledge of Forms of Sharing and Individual Platforms of the Sharing Economy}

Within the framework of the study, we first of all ascertained the scope in which respondents are familiar with the possibilities for sharing from the point of view of the individual segments of the sharing economy. We also ascertained whether any differences exist in familiarity among respondents from the point of view of traditional and developing segments of the sharing economy. As mentioned earlier, we regard shared accommodation and shared passenger transportation to be traditional segments.

Table 4 clearly shows knowledge of the individual forms of sharing within the framework of the possible segments of the sharing economy. Eleven of the thirteen forms evaluated are known by half or more of the respondents. Sharing accommodation and carpooling can be regarded as the best known, i.e. traditional segments of the sharing economy, knowledge of which was indicated by $82 \%$ of respondents.

Table 4

Knowledge of Forms of Sharing

\begin{tabular}{|l|c|c|}
\hline \multicolumn{1}{|c|}{ Forms of sharing } & N & \% \\
\hline Carpooling & 502 & $82 \%$ \\
\hline Sharing accommodation & 501 & $82 \%$ \\
\hline Sharing finances & 494 & $81 \%$ \\
\hline Carsharing & 473 & $77 \%$ \\
\hline $\begin{array}{l}\text { Electric scooter sharing and bicycle } \\
\text { sharing }\end{array}$ & 460 & $75 \%$ \\
\hline Sharing services & 426 & $69 \%$ \\
\hline Shared transport of goods or food & 408 & $66 \%$ \\
\hline Sharing tools and equipment & 352 & $57 \%$ \\
\hline Shared entertainment & 328 & $53 \%$ \\
\hline Sharing work or time & 316 & $51 \%$ \\
\hline Sharing space & 307 & $50 \%$ \\
\hline Shared education & 216 & $35 \%$ \\
\hline Sharing insurance & 214 & $35 \%$ \\
\hline
\end{tabular}

Forms of sharing such as carsharing, electric scooter sharing and bicycle sharing can also be regarded as very well-known, knowledge of these being declared by threequarters or more of the respondents. Sharing of finances can also be ranked among very well-known forms of sharing with $81 \%$ of the respondents knowing of its existence. 
We subsequently ascertained the scope in which respondents are familiar with the existence of individual platforms of the sharing economy (Table 5). We also ascertained whether any differences exist in knowledge of platforms from the point of view of traditional and developing segments.

Table 5

Knowledge of Individual Platforms of the Sharing Economy

\begin{tabular}{|c|c|c|c|}
\hline Segments/Forms & Platforms & $\mathbf{N}$ & $\%$ \\
\hline \multicolumn{4}{|l|}{ Accommodation } \\
\hline & Airbnb & 386 & $63 \%$ \\
\hline & Couchsurfing & 130 & $21 \%$ \\
\hline & Mojechaty & 119 & $19 \%$ \\
\hline & Flatio & 54 & $9 \%$ \\
\hline \multicolumn{4}{|c|}{ Passenger transportation } \\
\hline Carpooling & Uber & 487 & $79 \%$ \\
\hline Carpooling & Liftago & 245 & $40 \%$ \\
\hline Carpooling & Taxify & 197 & $32 \%$ \\
\hline Bicycle sharing & Rekola & 176 & $29 \%$ \\
\hline Carpooling & Blablacar & 128 & $21 \%$ \\
\hline Carsharing & Car4way & 93 & $15 \%$ \\
\hline Carsharing & HoopyGo & 33 & $5 \%$ \\
\hline \multicolumn{4}{|l|}{ Finance } \\
\hline & Zonky & 497 & $81 \%$ \\
\hline & Startovač & 132 & $22 \%$ \\
\hline & Fundlift & 50 & $8 \%$ \\
\hline & Crowder & 44 & $7 \%$ \\
\hline \multicolumn{4}{|l|}{ Other } \\
\hline Sharing services & Hlidačky.cz & 151 & $25 \%$ \\
\hline $\begin{array}{l}\text { Shared transport of } \\
\text { goods or food }\end{array}$ & Ubereats & 129 & $21 \%$ \\
\hline Sharing services & Nejremeslnici & 82 & $13 \%$ \\
\hline $\begin{array}{l}\text { Shared transport of } \\
\text { goods or food }\end{array}$ & Zavezu & 79 & $13 \%$ \\
\hline Sharing work or time & Supersoused & 53 & $9 \%$ \\
\hline $\begin{array}{l}\text { Sharing tools and } \\
\text { equip. }\end{array}$ & SharyGo & 39 & $6 \%$ \\
\hline Sharing work or time & LidskaSila & 33 & $5 \%$ \\
\hline
\end{tabular}

Knowledge of individual platforms of the sharing economy is clear from Table 5. From the point of view of familiarity with them, the Zonky platform (81\%) from the finance segment, the Uber platform $(79 \%)$ from the passenger transportation segment and the Airbnb platform (63\%) from the accommodation segment can be ranked among the TOP 3 platforms. Other monitored platforms, apart from the Liftago platform (40\%), are known by less than a third of respondents. Respondents also declared their knowledge of other platforms (e.g. Lime, Nextbike, FlixBus, Booking.com, Trivago, Trustroots, Kickstarter, Hithit, or damejidlo.cz), but only in a few cases.

The survey which was performed also shows that not a single platform from the passenger transportation segment is known to $14 \%$ of respondents, $15 \%$ know none from the finance segment, $26 \%$ know none from the accommodation segment and $48 \%$ of respondents do not know a single platform from the other segments of the sharing economy.

\section{Use of Individual Platforms of the Sharing Economy}

Within the framework of the study, we also ascertained the scope in which respondents use the services of selected platforms of the sharing economy (Table 6). At the same time, we ascertained whether any differences exist in use of the services of platforms of the sharing economy from the point of view of traditional and developing segments of the sharing economy.

Table 6

Use of Individual Platforms of the Sharing Economy

\begin{tabular}{|l|l|c|c|}
\hline Segments/Forms & Platforms & N & \% \\
\hline Accommodation & & & \\
\hline \multirow{5}{*}{ Passenger transportation } & 162 & $26 \%$ \\
\cline { 2 - 4 } & Mojechaty & 24 & $4 \%$ \\
\cline { 2 - 4 } & Couchsurfing & 23 & $4 \%$ \\
\hline Carpooling & Uber & 1 & $0.2 \%$ \\
\hline Carpooling & Taxify & 156 & $25 \%$ \\
\hline Carpooling & Liftago & 59 & $10 \%$ \\
\hline Carpooling & Blablacar & 37 & $6 \%$ \\
\hline Bicycle sharing & Rekola & 29 & $5 \%$ \\
\hline Carsharing & Car4way & 9 & $2 \%$ \\
\hline Carsharing & HoopyGo & 4 & $1 \%$ \\
\hline Finance & & & \\
\hline \multirow{7}{*}{$\begin{array}{l}\text { Zonky } \\
\text { Other }\end{array}$} & Startovač & 20 & $3 \%$ \\
\cline { 2 - 4 } & Fundlift & 2 & $0.5 \%$ \\
\cline { 2 - 4 } & Crowder & 1 & $0.2 \%$ \\
\hline Sharing services & & & \\
\hline $\begin{array}{l}\text { Shared transport of } \\
\text { goods or food }\end{array}$ & Hlidačky.cz & 19 & $3 \%$ \\
\hline Sharing services & Ubereats & 25 & $4 \%$ \\
\hline $\begin{array}{l}\text { Shared transport of } \\
\text { goods or food }\end{array}$ & Nejremeslnici & 11 & $2 \%$ \\
\hline Sharing work or time & Zavezu & 12 & $2 \%$ \\
\hline $\begin{array}{l}\text { Sharing tools and } \\
\text { equip. }\end{array}$ & Supersoused & 3 & $1 \%$ \\
\hline Sharing work or time & LidskaSila & 1 & $0.2 \%$ \\
\hline
\end{tabular}

At the start of this section, it is necessary to mention that 360 (i.e. $59 \%$ ) of respondents stated that they had not used any of the platforms of the sharing economy as a user yet.

The scope in which respondents participated as users in sharing via the individual platforms of the sharing economy is evident from Table 6 . It must be added that three respondents also stated that they use the Booking.com platform, two respondents that they used the damejidlo.cz platform and one respondent that they use the nesnezeno.cz platform.

Table 6 clearly shows that respondents use platforms in the accommodation and passenger transportation segments in the greatest scope. This specifically concerns the Airbnb (26\%) and Uber (25\%) platforms. Carpooling platforms rank among those platforms of the sharing economy which are used majorly from the point of view of the respondents we monitored.

\section{Knowledge of Forms of Sharing and Individual Platforms of the Sharing Economy in the Context of the Age of Respondents}

The subject of the study was also to ascertain whether any differences exist in the awareness of the individual forms of sharing and platforms of the sharing economy between the younger and the older generation. First of all, 
analysis was performed of the difference in familiarity with the individual forms of sharing between the younger generation aged 15 to 29 and the older generation aged 30 to 80 .

A statistically significant difference was proven in all of the thirteen monitored forms of sharing between the group of respondents up to the age of 29 and the group of respondents aged 30 and over. In all cases, the group of younger respondents exhibits a greater awareness of the possibilities for sharing in comparison with the group of older respondents. See Table 7.

Table 7

Knowledge of Forms of Sharing - Differences from the Point of View of the Younger and the Older Generation

\begin{tabular}{|c|c|c|c|c|}
\hline \multirow[b]{2}{*}{ Forms of sharing } & \multicolumn{2}{|c|}{ Relative frequency } & \multicolumn{2}{|c|}{ Chi-square test } \\
\hline & $\begin{array}{c}\text { Age } \\
15-29\end{array}$ & $\begin{array}{c}\text { Age } \\
\text { 30-80 }\end{array}$ & Chi-square & Sig. \\
\hline Carpooling & $94 \%$ & $75 \%$ & 34.000 & $<0.0005$ \\
\hline Sharing accommodation & $93 \%$ & $75 \%$ & 29.780 & $<0.0005$ \\
\hline Sharing finances & $91 \%$ & $75 \%$ & 24.659 & $<0.0005$ \\
\hline Carsharing & $88 \%$ & $71 \%$ & 21.828 & $<0.0005$ \\
\hline Electric scooter sharing and bicycle sharing & $87 \%$ & $68 \%$ & 27.637 & $<0.0005$ \\
\hline Sharing services & $84 \%$ & $61 \%$ & 37.321 & $<0.0005$ \\
\hline Shared transport of goods or food & $83 \%$ & $57 \%$ & 43.517 & $<0.0005$ \\
\hline Sharing tools and equipment & $70 \%$ & $50 \%$ & 23.473 & $<0.0005$ \\
\hline Shared entertainment & $68 \%$ & $45 \%$ & 31.394 & $<0.0005$ \\
\hline Sharing work or time & $66 \%$ & $43 \%$ & 30.118 & $<0.0005$ \\
\hline Sharing space & $65 \%$ & $41 \%$ & 32.499 & $<0.0005$ \\
\hline Shared education & $52 \%$ & $25 \%$ & 44,973 & $<0.0005$ \\
\hline Sharing insurance & $40 \%$ & $32 \%$ & 4.404 & 0.036 \\
\hline
\end{tabular}

Analysis was also performed of the difference in familiarity with individual platforms of the sharing economy between the younger generation aged 15 to 29 and the older generation aged 30 to 80 . A total of 22 platforms were used for the analysis, four from the accommodation segment, seven from the passenger transportation segment, four from the finance segment and seven from other segments of the sharing economy.

Table 8 clearly show that a statistically significant difference was proven in familiarity with the given platforms of the sharing economy between the younger and the older generation in fourteen cases. Of these, significantly greater familiarity with the given platforms is exhibited by representatives of the younger generation in thirteen cases. In only one case was a statistically significant difference proven in favour of the older generation.

The fact that the younger generation is better familiarised with the existence of platforms of the sharing economy is also confirmed by the data contained in Table 9. This table provides information about which proportion of respondents from the given group (younger and older generation) is familiar with the existence of at least one platform from the accommodation, passenger transportation, finance and other segments. A statistically significant difference was proven in all segments in general knowledge of platforms between the younger and the older generation. The younger generation exhibits a greater awareness of the platforms of the sharing economy which exist.

Table 8

Knowledge of Individual Platforms of the Sharing Economy - Differences from the Point of View of the Younger and the Older Generation

\begin{tabular}{|c|c|c|c|c|c|}
\hline \multirow[b]{2}{*}{ Segments/Forms } & \multirow[b]{2}{*}{ Platforms } & \multicolumn{2}{|c|}{ Relative frequency } & \multicolumn{2}{|c|}{ Chi-square test } \\
\hline & & $\begin{array}{c}\text { Age } \\
15-29\end{array}$ & $\begin{array}{c}\text { Age } \\
30-80\end{array}$ & Chi-square & Sig. \\
\hline \multicolumn{6}{|l|}{ Accommodation } \\
\hline & Airbnb & $77 \%$ & $55 \%$ & 31.176 & $<0.0005$ \\
\hline & Couchsurfing & $31 \%$ & $15 \%$ & 21.458 & $<0.0005$ \\
\hline & Mojechaty & $16 \%$ & $21 \%$ & 2.472 & 0.116 \\
\hline & Flatio & $13 \%$ & $7 \%$ & 6.036 & 0.014 \\
\hline \multicolumn{6}{|c|}{ Passenger transportation } \\
\hline Carpooling & Uber & $89 \%$ & $74 \%$ & 21.366 & $<0.0005$ \\
\hline Carpooling & Liftago & $61 \%$ & $28 \%$ & 63.698 & $<0.0005$ \\
\hline Carpooling & Taxify & $48 \%$ & $23 \%$ & 39.806 & $<0.0005$ \\
\hline Bicycle sharing & Rekola & $41 \%$ & $22 \%$ & 26.548 & $<0.0005$ \\
\hline Carpooling & Blablacar & $31 \%$ & $15 \%$ & 23.010 & $<0.0005$ \\
\hline Carsharing & Car4way & $19 \%$ & $13 \%$ & 3.563 & 0.059 \\
\hline Carsharing & HoopyGo & $9 \%$ & $4 \%$ & 6.696 & 0.010 \\
\hline \multicolumn{6}{|l|}{ Finance } \\
\hline & Zonky & $83 \%$ & $80 \%$ & 1.000 & 0.317 \\
\hline & Startovač & $32 \%$ & $16 \%$ & 21.732 & $<0.0005$ \\
\hline
\end{tabular}


Libena Tetrevova, Martina Jelinkova, Simona Munzarova. Traditional and Developing Segments of the Sharing...

\begin{tabular}{|l|l|c|c|c|c|}
\hline \multirow{2}{*}{ Segments/Forms } & \multirow{2}{*}{ Platforms } & \multicolumn{2}{|c|}{ Relative frequency } & \multicolumn{2}{c|}{ Chi-square test } \\
\cline { 2 - 6 } & & $\begin{array}{c}\text { Age } \\
\mathbf{1 5}-\mathbf{2 9}\end{array}$ & $\begin{array}{c}\text { Age } \\
\mathbf{3 0 - 8 0}\end{array}$ & \multirow{2}{*}{ Chi-square } & \multicolumn{2}{c|}{ Sig. } \\
\cline { 2 - 6 } & Fundlift & $11 \%$ & $7 \%$ & 3.116 & 0.078 \\
\cline { 2 - 6 } & Crowder & $9 \%$ & $6 \%$ & 1.647 & 0.199 \\
\hline Other & & $34 \%$ & $19 \%$ & $\mathbf{1 8 . 1 9 7}$ & $<\mathbf{0 . 0 0 0 5}$ \\
\hline Sharing services & Hlidačky.cz & $29 \%$ & $17 \%$ & $\mathbf{1 2 . 1 5 0}$ & $<\mathbf{0 . 0 0 0 5}$ \\
\hline Shared transport of goods or food & Ubereats & $5 \%$ & $18 \%$ & $\mathbf{1 9 . 4 9 5}$ & $<\mathbf{0 . 0 0 0 5}$ \\
\hline Sharing services & Nejremeslnici & $13 \%$ & $13 \%$ & 0.02 & 0.964 \\
\hline Shared transport of goods or food & Zavezu & $8 \%$ & $9 \%$ & 0.486 & 0.489 \\
\hline Sharing work or time & Supersoused & $9 \%$ & $5 \%$ & $\mathbf{3 . 9 3 7}$ & $\mathbf{0 . 0 4 7}$ \\
\hline Sharing tools and equip. & SharyGo & $5 \%$ & $5 \%$ & 0.0002 & 0.988 \\
\hline Sharing work or time & LidskaSila & & &
\end{tabular}

Table 9

General Knowledge of Platforms from Individual Segments of the Sharing Economy - Differences from the Point of View of the Younger and the Older Generation

\begin{tabular}{|l|c|c|c|c|}
\hline \multirow{3}{*}{ Segments } & \multicolumn{2}{|c|}{ Relative frequency } & \multicolumn{2}{|c|}{ Chi-square test } \\
\cline { 2 - 5 } & $\begin{array}{c}\text { Age } \\
\mathbf{1 5 - 2 9}\end{array}$ & $\begin{array}{c}\text { Age } \\
\mathbf{3 0}-\mathbf{8 0}\end{array}$ & \multirow{2}{*}{ Chi-square } & Sig. \\
\hline Accommodation & $86 \%$ & $68 \%$ & $\mathbf{2 3 . 5 9 5}$ & $<\mathbf{0 . 0 0 0 5}$ \\
\hline Passenger transportation & $96 \%$ & $80 \%$ & $\mathbf{3 1 . 1 9 9}$ & $<\mathbf{0 . 0 0 0 5}$ \\
\hline Finance & $89 \%$ & $82 \%$ & $\mathbf{5 . 0 1 3}$ & $\mathbf{0 . 0 2 5}$ \\
\hline Other & $59 \%$ & $48 \%$ & $\mathbf{6 . 3 2 3}$ & $\mathbf{0 . 0 1 2}$ \\
\hline
\end{tabular}

\section{Use of Individual Platforms of the Sharing Economy in the Context of the Age of Respondents}

Data was also ascertained as to whether any differences exist between the scope in which the younger and the older generation use individual platforms of the sharing economy. Similarly, as in the case of knowledge of platforms, 22 platforms were evaluated from the fields of accommodation, passenger transportation, finance and other.

Table 10 clearly shows that statistically significant differences in the scope of use of individual platforms was only proven in five cases, this being in the case of the accommodation platform Airbnb and four carpooling platforms (Uber, Taxify, Liftago and Blablacar).

Table 10

Use of Individual Platforms of the Sharing Economy - Differences from the Point of View of the Younger and the Older Generation

\begin{tabular}{|c|c|c|c|c|c|}
\hline \multirow[b]{2}{*}{ Segments/Forms } & \multirow[b]{2}{*}{ Platforms } & \multicolumn{2}{|c|}{ Relative frequency } & \multicolumn{2}{|c|}{ Chi-square test } \\
\hline & & $\begin{array}{c}\text { Age } \\
15-29\end{array}$ & $\begin{array}{c}\text { Age } \\
\text { 30-80 }\end{array}$ & Chi-square & Sig. \\
\hline \multicolumn{6}{|l|}{ Accommodation } \\
\hline & Airbnb & $37 \%$ & $21 \%$ & 18.975 & $<0.0005$ \\
\hline & Mojechaty & $3 \%$ & $5 \%$ & 1.421 & 0.233 \\
\hline & Couchsurfing & $3 \%$ & $4 \%$ & 0.377 & 0.539 \\
\hline & Flatio & $0 \%$ & $0.3 \%$ & 0.448 & 0.448 \\
\hline \multicolumn{6}{|l|}{ Passenger transportation } \\
\hline Carpooling & Uber & $32 \%$ & $22 \%$ & 7.360 & 0.007 \\
\hline Carpooling & Taxify & $13 \%$ & $7 \%$ & 5.813 & 0.016 \\
\hline Carpooling & Liftago & $9 \%$ & $4 \%$ & 5.246 & 0.022 \\
\hline Carpooling & Blablacar & $8 \%$ & $3 \%$ & 5.545 & 0.019 \\
\hline Bicycle sharing & Rekola & $6 \%$ & $4 \%$ & 1.827 & 0.176 \\
\hline Carsharing & Car4way & $1 \%$ & $2 \%$ & 0.802 & 0.371 \\
\hline Carsharing & HoopyGo & $0.4 \%$ & $1 \%$ & 0.229 & 0.632 \\
\hline \multicolumn{6}{|l|}{ Finance } \\
\hline & Zonky & $2 \%$ & $4 \%$ & 1.176 & 0.278 \\
\hline & Startovač & $1 \%$ & $2 \%$ & 0.184 & 0.668 \\
\hline & Fundlift & $0 \%$ & $0.5 \%$ & 1.152 & 0.283 \\
\hline & Crowder & $0 \%$ & $0.3 \%$ & 0.575 & 0.448 \\
\hline \multicolumn{6}{|l|}{ Other } \\
\hline Sharing services & Hlidačky.cz & $4 \%$ & $3 \%$ & 0.268 & 0.605 \\
\hline Shared transport of goods or food & Ubereats & $5 \%$ & $4 \%$ & 0.636 & 0.425 \\
\hline Sharing services & Nejremeslnici & $0.4 \%$ & $3 \%$ & 3.627 & 0.057 \\
\hline Shared transport of goods or food & Zavezu & $1 \%$ & $2 \%$ & 0.696 & 0.404 \\
\hline Sharing work or time & Supersoused & $0 \%$ & $1 \%$ & 1.732 & 0.188 \\
\hline Sharing tools and equip. & SharyGo & $0.4 \%$ & $0.5 \%$ & 0.013 & 0.910 \\
\hline Sharing work or time & LidskaSila & $0 \%$ & $0.3 \%$ & 0.575 & 0.448 \\
\hline
\end{tabular}




\section{Discussion and Conclusions}

The study shows that at least half of the respondents are aware of the fact that they can use carpooling, shared accommodation, sharing of finances, carsharing, electric scooter sharing and bicycle sharing, sharing of services, shared transport of goods and food, sharing of tools and equipment, sharing of entertainment, sharing of work and time and sharing of premises within the framework of the sharing economy model. Less than half of the respondents are aware of the fact that sharing can be used in the field of education or insurance. The respondents are the most aware of forms of sharing in the field of traditional segments of the sharing economy such as accommodation and passenger transportation (specifically carpooling, carsharing, electric scooter sharing and bicycle sharing). The conclusions reached in the past, for example by Bocker \& Meelen (2017), Cheng (2016), Frenken \& Schor (2017), Godelnik (2017), or Schor \& Cansoy (2019)., were thus confirmed. The respondents are also very well-informed about the possibility of sharing finances. This confirms the outlook of PwC (2016) forecasting growth in the importance of sharing finances. If we compare the findings we achieved with the results arrived at by Andreotti et al. (2017a) who analysed awareness of possible forms of sharing among 6,111 respondents from eleven Western European countries and Poland, we can state that the level of the awareness is comparable in the field of the traditional segments of the sharing economy - accommodation and passenger transportation. However, the awareness of the possibility of sharing finances is significantly higher, this being $46 \%$. On the basis of the above-mentioned, it is possible to state that hypothesis $\mathrm{H} 1$ (Customers are more familiar with options for sharing in the field of traditional segments of the sharing economy such as accommodation and transport as opposed to the other segments of the sharing economy.) was confirmed.

If we focus our attention on the differences in familiarity with the possibilities for or forms of sharing from a generational point of view, we can state that the younger generation (15-29) is significantly better informed about all of the monitored forms of sharing than the older generation (3080). The given finding was also reached, for example, by Andreotti et al. (2017a). Hypothesis H4 (The younger generation is more aware of the possible forms of sharing in comparison with the older generation.) was therefore confirmed.

The study we performed also shows that the respondents are familiar to the greatest extent with the existence of platforms from the personal transportation segment $\left(1^{\text {st }}\right.$ place), finance ( $2^{\text {nd }}$ place) and accommodation ( $3^{\text {rd }}$ place $)$. This means that it is not only platforms from traditional sectors of the sharing economy which are dominant, sectors such as accommodation (Airbnb) and personal transportation (Uber), the fundamental importance of which is referred to for example by Schor \& Cansoy (2019) or Godelnik (2017). A high level of familiarity is also evident as regards one of the financial platforms, this being the Zonky platform. In our opinion, this is associated with the extensive media campaign which has been conducted in the Czech Republic for several years now by this platform, in particular via television adverts. In 2019, for example, this platform spent EUR 4.6 million on advertising (Tramba,
2020). IPSOS (2020), a company which performs surveys mapping interest on the part of the Czech public in the sharing economy, also repeatedly ranks the Zonky, Uber and Airbnb platforms among the three best-known platforms of the sharing economy in the Czech Republic. For comparison, Andreotti et al. (2017a) rank Airbnb, Uber and Blablacar among the TOP platforms of the sharing economy. On the basis of the above-mentioned, we can state that hypothesis $\mathrm{H} 2$ (Customers are more familiar with the existence of platforms in the field of traditional segments of the sharing economy such as accommodation and transport as opposed to the other segments of the sharing economy.) was confirmed partially. This is to say that customers are the most familiar with platforms from the segment of passenger transportation and finance. The accommodation segment holds third place.

As regards differences in familiarity with the individual platforms of the sharing economy between the younger and the older generation, we can state that the younger generation exhibits a greater awareness as compared to the older generation. Statistically significant differences were proven in thirteen of the twenty-two platforms, this concerning platforms from the accommodation, passenger transportation and finance segments, as well as from the other segments of the sharing economy. Only in one case was a statistically significant difference proven in favour of the older generation, this being in the case of a platform which specialises in sharing trade services. IPSOS (2020) also came to the same conclusion in its study. Hypothesis H5 (The younger generation is more aware of the existence of platforms of the sharing economy in comparison with the older generation.) was therefore confirmed.

The study also shows that the respondents use two platforms belonging to traditional segments of the sharing economy in the greatest scope. This concerns the Airbnb platform (26\%), which belongs to the accommodation segment and the Uber platform (25\%), which belongs to the passenger transportation segment, specifically carpooling. We can therefore state that hypothesis H3 (Customers use the services of platforms in traditional segments of the sharing economy such as accommodation and transport to a greater extent as opposed to services in other segments of the sharing economy.) was confirmed. Similar findings are reached by the Eurobarometer (2018) study, according to which the population of the EU 28 used accommodation platforms in the greatest scope, followed by platforms in the passenger transportation segment. Among the two main reasons why they did not use platforms of the sharing economy, people living in the EU 28 stated that they did not know what sharing economy platforms were and also that they preferred traditional business models, in particular with regard to personal contact (Eurobarometer, 2018).

In the context of the above-mentioned findings about the difference in the awareness of the forms of sharing and platforms of the sharing economy between the younger and the older generation, the finding regarding the scope in which the younger and the older generation use the services of individual platforms of the sharing economy seems to be very interesting. With the exception of the accommodation platform Airbnb and four carpooling platforms, which are statistically used more by the younger generation, no other 
statistically significant differences were identified in use of the monitored platforms between the younger and the older generation. Hypothesis H6 (The younger generation uses the services of individual platforms of the sharing economy to a greater extent in comparison with the older generation.) was therefore not confirmed.

The research performed resulted in the following main conclusions and recommendations:

- It can be stated that in the Czech Republic, a relatively good awareness of the general possibilities of sharing exists in particular among the younger generation. On the basis of the level of familiarity with specific platforms ascertained, it seems that the given awareness is very strongly dependent on the media visibility of the specific sharing segment or platform, be this in the positive or negative sense of the word. It would therefore be appropriate to target an information campaign about the possibilities and usefulness of sharing at the older generation of potential users.

- Research uncovered a gap in knowledge and use of the investigated platforms from the "other" segment. For development of this segment, broader information support would seem to be of use, led by both the competent public authorities and private organisations - especially platforms. The reason for this is the potential which this segment of sharing offers from the point of view of the older generation.

- Use of the sharing platforms under investigation in the Czech Republic is relatively low for the time being. We believe that it would be advisable to increase people's confidence in the security and usefulness of using platforms in the sharing economy. This is a task both for the competent public administration authorities, in particular from the point of view of clarification of the legislative framework and positive media support, and also for the individual platforms, the functioning of which must be of a high quality, transparent and user-friendly. As already indicated above, we see great potential in involvement of the older generation. In their case, their motives relating to frugality, efficiency and saving on resources, which are characteristic for this generation, could be utilised. The fact that the former barrier of low computer literacy among older people is now disappearing also contributes towards the possibility of wider participation by the older generation in sharing. This makes this important field of the economy more accessible to people who may be interested of all ages.

In conclusion, it can be stated that the presented study is a source of knowledge both from a theoretical point of view and also a practical one. From a theoretical point of view, it contributes towards clarification of the view of alternative forms of sharing. This is to say that the issue of the sharing economy is a new topic, largely unexplored, and one which is also constantly developing (Gerwe \& Silva, 2020; Habibi et al., 2016). No basic typology is even available which could be used while researching this phenomenon. However, in view of the diversity of definitions and concepts of sharing, it is difficult to create universal topology. Proposal of typology of forms of sharing is provided in the article, based on the current state of knowledge, respecting the currently existing forms of sharing. The fact that the presented study broadens knowledge about the level of the awareness of the sharing economy and the scope of use of its platforms in one of the post-communist countries can be regarded as a further benefit on the border between theory and practice. The article therefore contributes towards filling in the gaps in research into this issue, one which in particular from the point of view of developing countries, is only of peripheral interest to researchers. From the point of view of practice, the study can be used both by current platform operators and also parties potentially interested in an offer of services within the framework of a sharing economy model, but also by the policy makers. The findings contained in this study can, for example, be used while creating strategy for influencing actual and potential users of platform services, among other things, in terms of their differentiation with regard to various age categories.

Despite the fact that it is a source of original findings, the presented study is associated with certain limiting factors. These may be regarded as the fact that it was performed under the conditions of a small post-communist country - the Czech Republic, in which this phenomenon is still developing. Another limiting factor is the chosen methodology, this being with regard to the choice of the forms of sharing and platforms of the sharing economy. We are aware that their definition was based on the current state of knowledge which will change over time. Last but not least, a limiting factor of the presented study is the fact that it engages in evaluation of status not causal relationships, which was however the intention of the authors in this part of the research.

In the context of the above-mentioned limiting factors, it is possible to determine possible future directions for research. First and foremost, we can recommend performance of comparative studies devoted to monitored issues on an international level, e.g. within the framework of V4 or EU 27 countries. Analysis can also be recommended of the impact of other factors such as education or life in the city or in a village on the scope of familiarity with forms of sharing, platforms of the sharing economy and the level of their use. Last but not least, we would recommend creation of a study analysing the opinions and attitudes of respondents towards selected aspects of the sharing economy, such as the reasons for participating or not participating in it, the level of its regulation or its economic, social and environmental impacts.

\section{Acknowledgements}

This article was supported by the project "Economic, Social and Environmental Aspects of Collaborative Economy from the Point of View of the Czech Republic"; COST Action CA16121 "From Sharing to Caring: Examining Socio-Technical Aspects of the Collaborative Economy". 


\section{References}

Adamiak, C. (2019). Current State and Development of Airbnb Accommodation Offer in 167 Countries. Current Issues in Tourism, 1-19. https://doi.org/10.1080/13683500.2019.1696758

Alarifi, A. (2015). Information assurance practices in Saudi Arabian organizations. In: C. Stephanidis (Ed.), HCI International 2015 - Posters' extended abstracts (pp. 637-642). Cham: Springer. https://doi.org/10.1007/978-3-31921383-5_106

Andreotti, A., Anselmi, G., Eichhorn, T., Hoffmann, C. P., Jürss, S., \& Micheli, M. (2017a). European Perspectives on Participation in the Sharing Economy. SSRN Electronic Journal. https://doi.org/10.2139/ssrn.3046550

Andreotti, A., Anselmi, G., Eichhorn, T., Hoffmann, C. P., \& Micheli, M. (2017b). Participation in the Sharing Economy. SSRN Electronic Journal. https://doi.org/10.2139/ssrn.2961745

Anglada, Q. M., \& Hernandez Lara, A. B. (2020). Research on Sharing Economy: Why Are Some Articles More Cited than Others? Economic Research-Ekonomska Istrazivanja, 33(1), 2787-2805. https://doi.org/10.1080/1331677 x.2019.1694427

Barnes, S. J., \& Mattsson, J. (2016). Understanding Current and Future Issues in Collaborative Consumption: A Four-stage Delphi Study. Technological Forecasting and Social Change, 104, 200-211. https://doi.org/10.1016/j.techfore. 2016.01.006

Belk, R. (2014). You Are what You Can Access: Sharing and Collaborative Consumption Online. Journal of Business Research, 67(8), 1595-1600. https://doi.org/10.1016/j.jbusres.2013.10.001

Bellos, I., Ferguson, M., \& Toktay, L. B. (2017). The Car Sharing Economy: Interaction of Business Model Choice and Product Line Design. Manufacturing \& Service Operations Management, 19(2), 185-201. https://doi.org/10. 1287/msom.2016.0605

Bokyeong, K., \& Cho, Y. C. (2016). Investigating the Impact of Justice Dimension and Perceived Value on Customer Satisfaction for Sharing Economy of Accommodation. Journal of Business \& Economics Research, 14(4), 153-170. https://doi.org/10.19030/jber.v14i4.9804

Botsman, R., \& Rogers, R. (2011). What's mine is yours. How collaborative consumption is changing the way we live. London: Collins.

Bocker, L., \& Meelen, T. (2017). Sharing for People, Planet or Profit? Analysing Motivations for Intended Sharing Economy Participation. Environmental Innovation and Societal Transitions, 23, 28-39. https://doi.org/10.1016/j.eist.2016.09.004

Bucher, E., Fieseler, C., \& Lutz, C. (2016). What's Mine is yours (for a Nominal Fee) - Exploring the Spectrum of Utilitarian to Altruistic Motives for Internet-mediated Sharing. Computers in Human Behavior, 62, 316-326. https://doi.org/10.10 16/j.chb.2016.04.002

Casado-Diaz, M. A., Casado-Diaz, A. B., \& Hoogendoorn, G. (2020). The Home Exchange Phenomenon in the Sharing Economy: A Research Agenda. Scandinavian Journal of Hospitality and Tourism, 20(3), 268-285. https://doi.org/10.10 80/15022250.2019.1708455

Chakrapani, C. (2000). Marketing research: State-of-the-art perspectives. Chicago: American Marketing Association.

Cheng, M. (2016). Sharing Economy: A Review and Agenda for Future Research. International Journal of Hospitality Management, 57, 60-70. https://doi.org/10.1016/j.ijhm.2016.06.003

Cheng, X., Fu, S., Sun, J., Bilgihan, A., \& Okumus, F. (2019). An Investigation on Online Reviews in Sharing Economy Driven Hospitality Platforms: A Viewpoint of Trust. Tourism Management, 71, 366-377. https://doi.org/10.10 16/j.tourman.2018.10.020

Choy, L. T. (2014). The Strengths and Weaknesses of Research Methodology: Comparison and Complimentary between Qualitative and Quantitative Approaches. IOSR Journal of Humanities and Social Science, 19(4), 99-104. https://doi.org/10.9790/0837-194399104

Cohen, B., \& Munoz, P. (2016). Sharing Cities and Sustainable Consumption and Production: Towards an Integrated Framework. Journal of Cleaner Production, 134, 87-97. https://doi.org/10.1016/j.jclepro.2015.07.133

Czech Statistical Office. (2018). Sharing Economy Services in the Czech Republic Have a Large Delay behind the European Average. Available from Internet: https://www.czso.cz/csu/stoletistatistiky/sluzby-sdilene-ekonomiky-v-cr-maji-zaevropskym-prumerem-velke-zpozdeni

De Rivera, J., Gordo, A., Cassidy, P., \& Apesteguia, A. (2017). A Netnographic Study of P2P Collaborative Consumption Platforms' User Interface and Design. Environmental Innovation and Societal Transitions, 23, 11-27. https://doi.org/10.1016/j.eist.2016.09.003

Demary, V. (2015). Competition in the sharing economy. IW Policy Paper No. 19. Koln: Institut der deutschen Wirtschaft. 
Dudek, D., \& Salek, R. (2016). The Concept of Sharing Goods as a Manifestation of Information Technology Transformation in Rural Areas. Zeszyty Naukowe Politechniki Częstochowskiej. Zarzadzanie (21), 124-133. https://doi.org/10. 17512/znpcz.2016.1.12

Elena-Bucea, A., Cruz-Jesus, F., Oliveira, T., \& Coelho, P. S. (2020). Assessing the Role of Age, Education, Gender and Income on the Digital Divide: Evidence for the European Union. Information Systems Frontiers. https://doi.org/10. 1007/s10796-020-10012-9

Ertz, M., Durif, F., \& Arcand, M. (2019). A Conceptual Perspective on Collaborative Consumption. AMS Review, 9(1/2), 27-41. https://doi.org/10.1007/s13162-018-0121-3

Ertz, M., Durif, F., \& Arcand, M. (2017). An Analysis of the Origins of Collaborative Consumption and Its Implications for Marketing. Academy of Marketing Studies Journal, 27(1), 1-17. https://doi.org/10.1007/s13162-018-0121-3

Eurobarometer. (2018). The Use of the Collaborative Economy. Available from Internet: https://data.europa.eu/euodp/ en/data/dataset/S2184_467_ENG

European Commission. (2019). Are You Part of the Collaborative Economy? Available from Internet: https://ec.europa.eu/eurostat/web/products-eurostat-news/-/DDN-20190416-

1 ? inheritRedirect=true\&redirect=/eurostat/+

European Commission. (2016). Communication from the Commission to the European Parliament, the Council, the European Economic and Social Committee and the Committee of the Regions. A European Agenda for the Collaborative Economy. $\operatorname{COM(2016)~356.~Available~from~Internet:~https://eur-lex.europa.eu/legal-content/EN/TXT/PDF/?uri=~}$ CELEX:52016DC0356\&from=EN

Fabo, B., Beblavy, M., Kilhoffer, Z., \& Lenaerts, K. (2017). An overview of European platforms: Scope and business models. Luxembourg: Publications Office of the European Union. https://doi.org/10.2760/762447

Ferrell, O. C., Ferrell, L., \& Huggins, K. (2017). Seismic Shifts in the Sharing Economy: Shaking up Marketing Channels and Supply Chains. Journal of Marketing Channels, 24(1/2), 3-12. https://doi.org/10.1080/1046669x.2017.1346973

Frenken, K., \& Schor, J. (2017). Putting the Sharing Economy into Perspective. Environmental Innovation and Societal Transitions, 23, 3-10. https://doi.org/10.1016/j.eist.2017.01.003

Geissinger, A., Laurell, C., Oberg, C., \& Sandstrom, C. (2019). How Sustainable is the Sharing Economy? On the Sustainability Connotations of Sharing Economy Platforms. Journal of Cleaner Production, $206,419-429$. https://doi.org/10.1016/j.jclepro.2018.09.196

Gerwe, O., \& Silva, R. (2020). Clarifying the Sharing Economy: Conceptualization, Typology, Antecedents, and Effects. Academy of Management Perspectives, 34(1), 65-96. https://doi.org/10.5465/amp.2017.0010

Godelnik, R. (2017). Millennials and the Sharing Economy: Lessons from a "Buy Nothing New, Share Everything Month" Project. Environmental Innovation and Societal Transitions, 23, 40-52. https://doi.org/10.1016/j.eist.2017.02.002

Gorog, G. (2018). The Definitions of Sharing Economy: A Systematic Literature Review. Management, 13(2), $175-189$. https://doi.org/10.26493/1854-4231.13.175-189

Gruszka, K. (2017). Framing the Collaborative Economy - Voices of Contestation. Environmental Innovation and Societal Transitions, 23, 92-104. https://doi.org/10.1016/j.eist.2016.09.002

Guyader, H., \& Kienzler, M. (2019). "True Sharing" or "Sharing Economy" Fad?. Available from Internet: http://www.divaportal.org/smash/record.jsf?pid=diva2\%3A1352344\&dswid=1715

Guyader, H., \& Piscicelli, L. (2019). Business Model Diversification in the Sharing Economy: The Case of GoMore. Journal of Cleaner Production, 215, 1059-1069. https://doi.org/10.1016/j.jclepro.2019.01.114

Habibi, M. R. (2019). The Progression and Impact of the Sharing Economy; a Preface. Journal of Marketing Theory and Practice, 27(4), 349-354. https://doi.org/10.1080/10696679.2019.1644959

Habibi, M. R., Kim, A., \& Laroche, M. (2016). From Sharing to Exchange: An Extended Framework of Dual Modes of Collaborative Nonownership Consumption. Journal of the Association for Consumer Research, 1(2), $277-294$. https://doi.org/10.1086/684685

Hamari, J., Sjoklint, M., \& Ukkonen, A. (2016). The Sharing Economy: Why People Participate in Collaborative Consumption. Journal of the Association for Information Science and Technology, 67(9), 2047-2059. https://doi.org/10.1002/asi.23552

Harvey, J., Smith, A., Goulding, J., \& Branco Illodo, I. (2020). Food Sharing, Redistribution, and Waste Reduction via Mobile Applications: A Social Network Analysis. Industrial Marketing Management. 88, 437-448. https://doi.org/10.1016/j.indmarman.2019.02.019

IPSOS. (2020). Interest in the Sharing Economy is Growing. Available from Internet: https://www.ipsos.com/cs-cz/zajemo-sdilenou-ekonomiku-roste-vyzkousel-ji-uz-kazdy-treti-cech 
Kathan, W., Matzler, K., \& Veider, V. (2016). The Sharing Economy: Your Business Model's Friend or Foe? Business Horizons, 59(6), 663-672. https://doi.org/10.1016/j.bushor.2016.06.006

Kealey, D. J., \& Protheroe, D. R. (1996). The Effectiveness of Cross-cultural Training for Expatriates: An Assessment of the Literature on the Issue. International Journal of Intercultural Relations, 20(2), 141-165. https://doi.org/10.1016/ 0147-1767(96)00001-6

Laukkanen, M., \& Tura, N. (2020). The Potential of Sharing Economy Business Models for Sustainable Value Creation. Journal of Cleaner Production, 253, 120004. https://doi.org/10.1016/j.jclepro.2020.120004

Leone, D., \& Schiavone, F. (2018). Innovation and Knowledge Sharing in Crowdfunding: How Social Dynamics Affect Project Success. Technology Analysis \& Strategic Management, 31(7), 803-816. https://doi.org/10.1080/ 09537325.2018.1554858

Lessem, R., Muchineripi, P. C., \& Kada, S. (2016). Integral community: Political economy to social commons. New York, NY: Routledge. https://doi.org/10.4324/9781315588896

Liaw, S. S. (2002). An Internet Survey for Perceptions of Computers and the World Wide Web: Relationship, Prediction, and Difference. Computers in Human Behavior, 18(1), 17-35. https://doi.org/10.1016/s0747-5632(01)00032-2

Manstead, A. S. R., \& Livingstone, A. G. (2012). Research methods in social psychology. In: M. Hewstone, W. Stroebe, \& K. Jonas (Eds.), an introduction to social psychology (pp. 25-54). 5th ed. Glasgow: John Wiley \& Sons.

Markendahl, J., Hossain, M. I., Mccormick, K., Lund, T., Moller, J., \& Naslund, P. (2018). Analysis of Sharing Economy Services: Initial Findings from Sharing Cities Sweden. Nordic and Baltic Journal of Information and Communications Technologies, (1), 239-260. https://doi.org/10.13052/nbjict1902-097x.2018.013

Mattsson, J., \& Barnes, S. (2016). Understanding Current and Future Issues in Collaborative Consumption: A Four-Stage Delphi Study. Technological Forecasting and Social Change, 104, 200-211. https://doi.org/10.1016/ j.techfore.2016.01.006

Matveev, A. V. (2002). The Advantages of Employing Quantitative and Qualitative Methods in Intercultural Research: Practical Implications from the Study of the Perceptions of Intercultural Communication Competence by American and Russian Managers. Bulletin of Russian Communication Association "Theory of Communication and Applied Communication", 1, 59-67.

May, S., Konigsson, M., \& Holmstrom, J. (2017). Unlocking the Sharing Economy: Investigating the Barriers for the Sharing Economy in a City Context. First Monday, 22(2). https://doi.org/10.5210/fm.v22i2.7110

McKee, D. (2017). Neoliberalism and the Legality of Peer Platform Markets. Environmental Innovation and Societal Transitions, 23, 105-113. https://doi.org/10.1016/j.eist.2017.04.001

Meadows, K. A. (2003). So You Want to Do Research?: Questionnaire Design. British Journal of Community Nursing, 8(12), 562-570. https://doi.org/10.12968/bjcn.2003.8.12.11854

Mi, Z., \& Coffman, D. (2019). The Sharing Economy Promotes Sustainable Societies. Nature Communications, 10(1). https://doi.org/10.1038/s41467-019-09260-4

Milanova, V., \& Maas, P. (2017). Sharing Intangibles: Uncovering Individual Motives for Engagement in a Sharing Service Setting. Journal of Business Research, 75, 159-171. https://doi.org/10.1016/j.jbusres.2017.02.002

Munoz, P., \& Cohen, B. (2017). Mapping out the Sharing Economy: A Configurational Approach to Sharing Business Modeling. Technological Forecasting and Social Change, 125, 21-37. https://doi.org/10.1016/j.techfore.2017.03.035

Nijland, H., \& van Meerkerk, J. (2017). Mobility and Environmental Impacts of Car Sharing in the Netherlands. Environmental Innovation and Societal Transitions, 23, 84-91. https://doi.org/10.1016/j.eist.2017.02.001

Parente, R. C., Geleilate, J.-M. G., \& Rong, K. (2018). The Sharing Economy Globalization Phenomenon: A Research Agenda. Journal of International Management, 24(1), 52-64. https://doi.org/10.1016/j.intman.2017.10.001

Pepic, L. (2018). The Sharing Economy: Uber and its Effect on Taxi Companies. Acta Economica, 16(28). https://doi.org/10.7251/ace1828123p

Puschmann, T., \& Alt, R. (2016). Sharing Economy. Business \& Information Systems Engineering, 58(1), 93-99. https://doi.org/10.1007/s12599-015-0420-2

PwC. (2016). The Sharing Economy Presents Europe with a $€ 570$ Billion Opportunity. Available from Internet: https://www.pwc.com/hu/ en/pressroom/2016/sharing_economy_europe.html

PwC. (2015). Sharing or Paring? Growth of the Sharing Economy. Available from Internet: https://www.pwc.com/hu/en/kiadvanyok/assets/pdf/sharing-economy-en.pdf

Rada, V. D. de, \& Martin, V. M. (2014). Random Route and Quota Sampling: Do They Offer Any Advantage over Probably Sampling Methods? Open Journal of Statistics, 4(5), 391-401. https://doi.org/10.4236/ojs.2014.45038 
Libena Tetrevova, Martina Jelinkova, Simona Munzarova. Traditional and Developing Segments of the Sharing...

Radwan, M. B., Patsiaouras, G., \& Saren, M. (2019). To Own or to Access? An Exploration of Sharing and Access Practices by Arab Millennials. In: R. W. Belk, G. M. Eckhardt, \& F. Bardhi (Eds.). Handbook of the Sharing Economy (pp. 6274). Cheltenham: Edward Elgar Publishing. https://doi.org/10.4337/9781788110549.00012

Richardson, L. (2015). Performing the Sharing Economy. Geoforum, 67, 121-129. https://doi.org/10.1016/ j.geoforum.2015.11.004

Richter, H., \& Slowinski, P. R. (2018). The Data Sharing Economy: On the Emergence of New Intermediaries. IIC International Review of Intellectual Property and Competition Law, 50(1), 4-29. https://doi.org/10.1007/s40319-01800777-7

Ritter, M., \& Schanz, H. (2019). The Sharing Economy: A Comprehensive Business Model Framework. Journal of Cleaner Production, 213, 320-331. https://doi.org/10.1016/j.jclepro.2018.12.154

Schneider, D. (2017). Rewarding Prosociality on Non-commercial Online Sharing Platforms. In Proceedings of the 25th European Conference on Information Systems (ECIS), Guimarães, Portugal, June 5-10, 2017, 2269-2284.

Schor, J. (2016). Debating the Sharing Economy. Journal of Self-Governance and Management Economics, 4(3), 7-22. https://doi.org/10.22381/jsme4320161

Schor, J. B., \& Cansoy, M. (2019). The sharing economy. In F. F. Wherry, \& I. Woodward (Eds.), The Oxford handbook of consumption (pp. 51-74). Oxford: Oxford University Press. https://doi.org/10.1093/oxfordhb/9780190695583.013.32

Standing, C., Standing, S., \& Biermann, S. (2019). The Implications of the Sharing Economy for Transport. Transport Reviews, 39(2), 226-242. https://doi.org/10.1080/01441647.2018.1450307

Stanoevska-Slabeva, K., Lenz-Kesekamp, V., \& Suter, V. (2017). Platforms and the Sharing Economy: An Analysis. SSRN Electronic Journal. https://doi.org/10.2139/ssrn.3102184

Sujova, A., \& Remen, O. (2018). Management of Changes in Business Processes: An Empirical Study in Slovak Enterprises. Engineering Management in Production and Services, 10(3), 37-50. https://doi.org/10.2478/emj-2018-0015

Sutherland, W., \& Jarrahi, M. H. (2018). The Sharing Economy and Digital Platforms: A Review and Research Agenda. International Journal of Information Management, 43, 328-341. https://doi.org/10.1016/j.ijinfomgt.2018.07.004

Siuskaite, D., Pilinkiene, V., \& Zvirdauskas, D. (2019). The Conceptualization of the Sharing Economy as a Business Model. Engineering Economics, 30(3), 373-381. https://doi.org/10.5755/j01.ee.30.3.21253

Tetrevova, L. (2020). Options for Use of Charitable Sharing for Protection of Public Health During the COVID-19 Pandemic Experience from the Czech Republic. Verejna Sprava a Spolocnost', 21(1), 21-32. https://doi.org/10.33542/vss2020-1-02

Tetrevova, L., \& Kolmasova, P. (2021). Possibilities of the Sharing Economy from the Point of View of Chemical Companies. Chemicke listy, 115(5): 280-285.

Tetrevova, L., \& Vlckova, V. (2019). Academic Entrepreneurship in the Czech Republic. Ekonomicky casopis, 67(9), 9951010.

Tetrevova, L., \& Vlckova, V. (2018). Benefits, Limitations, and Measures Concerning the Development of Cooperation between Higher Education Institutions and External Entities. Tertiary Education and Management, 24(4), 377-394. https://doi.org/10.1080/13583883.2018.1476579

Thornton, P. R., Williams, A. M., \& Shaw, G. (1997). Revisiting Time - Space Diaries: An Exploratory Case Study of Tourist Behaviour in Cornwall, England. Environment and Planning A: Economy and Space, 29(10), $1847-1867$. https://doi.org/10.1068/a291847

Tramba, D. (2020). Zonky Suffers a Million Crowns a Day. Available from Internet: https://www.tydenikhrot.cz/clanek/ zonky-prodelava-milion-korun-denne

Voytenko Palgan, Y., Zvolska, L., \& Mont, O. (2017). Sustainability Framings of Accommodation Sharing. Environmental Innovation and Societal Transitions, 23, 70-83. https://doi.org/10.1016/j.eist.2016.12.002

Wei, Z., \& Lin, M. (2017). Market Mechanisms in Online Peer-to-Peer Lending. Management Science, 63(12), $4236-4257$. https://doi.org/10.1287/mnsc.2016.2531

Wright, K. B. (2006). Researching Internet-Based Populations: Advantages and Disadvantages of Online Survey Research, Online Questionnaire Authoring Software Packages, and Web Survey Services. Journal of Computer-Mediated Communication, 10(3). doi:10.1111/j.1083-6101.2005.tb00259.x

Zhang, T. C., Gu, H., \& Jahromi, M. F. (2019). What Makes the Sharing Economy Successful? An Empirical Examination of Competitive Customer Value Propositions. Computers in Human Behavior, 95, 275-283. https://doi.org/10. 1016/j.chb.2018.03.019

Zhu, G., So, K. K. F., \& Hudson, S. (2017). Inside the Sharing Economy: Understanding Consumer Motivations behind the Adoption of Mobile Applications. International Journal of Contemporary Hospitality Management, 29(9), $2218-2239$. https://doi.org/10.1108/ijchm-09-2016-0496 


\section{Authors' Biographies}

Libena Tetrevova is an Associate Professor in Business and Management Studies at the University of Pardubice, Faculty of Chemical Technology; a researcher in the research group Corporate Social Responsibility and Sharing Economy. Her research interests are focused on corporate social responsibility, university social responsibility, sharing economy and partnership management. ORCID iD 0000-0001-5241-545X

Martina Jelinkova is an Assistant Professor in Marketing and Social Communication at the University of Pardubice, Faculty of Chemical Technology; a researcher in the research group Corporate Social Responsibility and Sharing Economy. In her scientific work, she focuses on marketing research and social communication. ORCID iD 0000-0003-3115-9770

Simona Munzarova is an Assistant Professor in Business and Management and Management Science Modelling Studies at the University of Pardubice, Faculty of Chemical Technology; a researcher in the research group Corporate Social Responsibility and Sharing Economy. In her scientific work, she focuses on environmental management and corporate social responsibility. ORCID iD 0000-0002-7886-9596

The article has been reviewed. Received in January 2021; accepted in December 2021. 